Creative Commons User License: CC BY-NC-ND

Abstracted by: EBSCOhost, Electronic Journals Service (EJS),

Google Scholar, Journal Seek, Scientific Commons,

Food and Agricultural Organization (FAO), CABI and Scopus

http://eoi.citefactor.org/10.11226/v24i4
Journal of Agricultural Extension

Vol. 24 (4) October, 2020

ISSN(e): 24086851; ISSN(Print); 1119944X

http://journal.aesonnigeria.org

http://www.ajol.info/index.php/iae

Email: editorinchief@aesonnigeria.org

\title{
Factors Influencing Involvement of Youth in Poultry Production in Abia State, Nigeria \\ https://dx.doi.org/10.4314/jae.v24i4.16
}

\section{Nmeregini, Daniel Chinomso}

Department of Agricultural Extension and Rural Development, Michael Okpara University of Agriculture Umudike, Abia state, Nigeria.

d.cnmeregini@yahoo.com, 08131131206

\section{Onuekwusi, Gideon Chinedu}

Department of Agricultural Extension and Rural Development, Michael Okpara University of Agriculture Umudike, Abia state, Nigeria

gideononuekwusi@gmail.com, 08037753165

\section{Ekweanya, Ndidiamaka Martha}

Department of Agricultural Extension and Rural Development, Michael Okpara University of Agriculture

Umudike, Abia state, Nigeria.

amakahyginus7@gmail.com, 08069603859

\section{Elezue, Chinyere Sarah}

Department of Agricultural Extension and Rural Development, Michael Okpara University of Agriculture Umudike, Abia state, Nigeria.

Elezuesarah24@gmail.com, 08153109659

\section{Abstract}

The study assessed the factors influencing the involvement of youths in poultry production in Abia State, Nigeria. Specifically, the study assessed the extent of youth's involvement in poultry production; and ascertained the perceived factors that influence the involvement of youths in poultry production. Multistage sampling procedure was employed in selecting 120 young poultry farmers. Data collected were analyzed using percentage, and mean, as well as ordinary least square regression analysis. Results revealed that the youths in the study area participated moderately in poultry production and the foremost poultry production activities being participated by the youths included feeding $(\bar{x}=2.81)$, packing and replacement of litters $(\bar{x}=2.59)$, and vaccination/medication ( $\bar{x}=2.54)$. Moreover, the perceived factors influencing the youths' involvement in poultry production were income $(\bar{x}=3.69)$, cost of feed $(\bar{x}=3.45)$, and availability of land $(\bar{x}=3.33)$. The coefficients of age (0.013), membership to co-operative (0.042), years of experience (0.016), and extension contact (0.015) were positive and significantly influenced the involvement of the youths in poultry production. Enabling youths' access to credits, subsidizing the cost of feed, and organizing training for the youths on poultry production were recommended.

Keywords: Involvement, agripreneurship, poultry production, youths 
Creative Commons User License: CC BY-NC-ND

Abstracted by: EBSCOhost, Electronic Journals Service (EJS),

Google Scholar, Journal Seek, Scientific Commons,

Food and Agricultural Organization (FAO), CABI and Scopus
Journal of Agricultural Extension

Vol. 24 (4) October, 2020

ISSN(e): 24086851; ISSN(Print); 1119944X

http://journal.aesonnigeria.org

http://www.ajol.info/index.php/iae

Email: editorinchief@aesonnigeria.org

\section{Introduction}

The quest to bridge the gap in unemployment and ensure increased economic opportunities and food security for the rural households especially among the youths has necessitated the adoption of agripreneurship (Nwibo, Mbam, and Biam, 2016). Agripreneurship can be seen as a process whereby youths become determined, creative, innovative, willing to take calculated risk, always looking for opportunities to improve and expand their farm business. It simply means entrepreneurship in agriculture. Agripreneurship is necessary for the socio-economic upliftment of the greater population through creation of new agribusinesses, agricultural commodities value chains and overall economic growth (Nwibo et al, 2016).

The poultry production is among the foremost important agripreneurship venture being involved by the youths in Nigeria after crop production (Onuekwusi, Nmeregini, Amanze, 2019). Poultry refers to the birds which are domesticated by man for egg or meat production. It includes such birds like chicken, ducks, geese, turkeys, pigeon, guinea fowl, quail etc. Poultry production involves the breeding, tending and/or raising of poultry to produce eggs and meat (Nwarieji, Obi and Ejiofor, 2017). The poultry industry has remained the most dynamic and fastest growing segment in the animal husbandry subsector. It constitutes about 58.72 per cent of the total livestock resources in Nigeria and many people have gone into poultry production either producing egg or meat or both (Adeniran, Akinnagbe, Obute and Olatunji, 2018).

The importance of poultry to national economy cannot be over emphasized as it has become popular for the small-holders that have contributed to the economy of the country. The poultry sub-sector occupies a prominent position in providing the needed animal protein, minerals and vitamins to balance the human diet (Adeniran et al, 2018). In Nigeria, poultry contributes about 15 percent of the total annual protein intake with approximately $1.3 \mathrm{~kg}$ of poultry products consumed per head per annum (Osuji, 2019). Apart from the provision of needed protein, the poultry industry serves as source of income, employment and poverty alleviation. Production of poultry is seen to be a part of rural life in most rural Africa where youth form part of the workforce. Approximately $80 \%$ of rural households are involved in smallholder poultry production (Heinke, Alexandra, and Ludwig, 2015).

Hitherto, the poultry sector is one of the agro-entrepreneurial area with great potential and untapped prospect of empowering the youths in Abia State (Ajani, Mgbenka, and Onah, 2015). Poultry serves as significant source of quality animal protein from meat and eggs with high biological value than plant proteins. It provides ready income and development to many households in Nigeria, in addition to having quickest and highest rate of return of investment (short generation), ease of management and small space requirement (Inyang and Eko, 2015).

According to Adedeji, Amao, Alabi, and Opebiyi, (2015), poultry production is influenced by some factors which are: types of poultry (birds), housing, socioeconomic background of the respondent, health and disease, feed source and feeding, sales and disposal. The involvement of youths in poultry production is mostly hampered by factors, such as access to land, lack of start-up capital, high 
Creative Commons User License: CC BY-NC-ND

Abstracted by: EBSCOhost, Electronic Journals Service (EJS),

Google Scholar, Journal Seek, Scientific Commons,

Food and Agricultural Organization (FAO), CABI and Scopus
Journal of Agricultural Extension

Vol. 24 (4) October, 2020

ISSN(e): 24086851; ISSN(Print); 1119944X

http://journal.aesonnigeria.org

http://www.ajol.info/index.php/jae

Email: editorinchief@aesonnigeria.org

cost of feed, lack of required management skills, and problem of disease resulting to high mortality (Njenga, Mugo, and Opiyo, 2014; Ezeibe, Okorji, Chah, and Abudei, 2014). Similarly, Ezeano, Ume, Okeke, Gbughemobi, (2017) identified awareness of agriculture programme, years of farming experience, farm size, level of education as significant factors affecting the level of youth participation in poultry production.

However, despite the vast opportunities abounding in poultry production and its potency in reducing the rate of unemployment among the youths and its role in improving the living condition of rural households, its development has not been fully embraced by the youths (Nwigbo et al, 2016). Youth engagement and interest in agripreneurship including poultry production in Nigeria has been low recently. Generally, youth worldwide have lacked motivation to enter and persist in the agro enterprise (Food and Agricultural Organization, 2017). Potential entry into the poultry enterprise has carried a host of challenges and entry barriers such as insufficient access to knowledge, information and education and limited access to land, financial services, markets, disease outbreaks, poor quality chicks, high cost of feed, and involvement of quacks as well as concerns about environmental pollution from poultry manures (Inyang and Eko, 2015; FAO, 2017).

Furthermore, despite worrying accounts of youth's interest in poultry production and other agripreneurship areas, there has not been adequate research done to capture the determinants of youth's involvement in agripreneurship in poultry production among the youths in Nigeria and Abia State in particular. According to Akpan, Patrick, James, and Agom (2015), the decision of youth to participate in agripreneurship has a lot to do with the cultural, political, environmental and economic situation of a society. The youths are vulnerable to change either positive or negative. Hence, it becomes pertinent to identify those determinant variables that drive youth's decision towards agripreneurship in poultry in Abia State.

\section{Purpose of study}

The study assessed the factors influencing involvement of youth in poultry production in Abia State, Nigeria. Specifically, the study assessed the extent of youth's involvement in poultry production; and ascertained the perceived factors influencing the involvement of youths in poultry production.

Ho1: The socio-economic characteristics of the youths have no significant influence on their involvement in poultry production in Abia State.

\section{Methodology}

This study was conducted in Abia state, Nigeria. The state lies between Longitude $04^{\circ} 45^{\prime}$ and $06^{\circ} 17^{\prime}$ North, and Latitude 0700' and $08^{\circ} 10^{\prime}$ East. The State is located within the forest belt of Nigeria, and the temperature ranges between $20^{\circ} \mathrm{C}$ and $36^{\circ}$ C. The state covers a land mass of about $5,243.7 \mathrm{~km} 2$. (Independent National Electoral Commission, (INEC) 2008). The 2016 population of the state is estimated as $3,727,347$ persons (NBS, 2017). The state comprises of seventeen (17) local 
Creative Commons User License: CC BY-NC-ND

Abstracted by: EBSCOhost, Electronic Journals Service (EJS),

Google Scholar, Journal Seek, Scientific Commons,

Food and Agricultural Organization (FAO), CABI and Scopus
Journal of Agricultural Extension

Vol. 24 (4) October, 2020

ISSN(e): 24086851; ISSN(Print); 1119944X

http://journal.aesonnigeria.org

http://www.aiol.info/index.php/iae

Email: editorinchief@aesonnigeria.org

http://eoi.citefactor.org/10.11226/v24i4

government areas (LGAs), with Umuahia as its capital. Agriculturally, the state is divided into three (3) agricultural zones, namely; Aba, Ohafia and Umuahia zones. A multi-stage sampling procedure was employed in selecting the sample for the study. The first stage involved a random selection of one agricultural zone out the three zones. In the second stage, three blocks were randomly selected from the zone. The third stage involved a purposive selection of four cells from each of the selected blocks based on the level of poultry production, thus making a total of 12 cells. In the fourth stage, two circles were selected from each of the selected cells. Then, from each of the selected circles, five youths were purposively selected based on their involvement in poultry production. Thus making a total sample size of 120 youths.

Data were generated through the use of structured questionnaire. Data were analysed using percentages and mean. The extent of youth's involvement in poultry production was measured on a three points rating scale of always (3), occasionally (2), not at all (1). The benchmark mean of 2.0 was used for decision making. Decision: $\bar{x}_{\geq 2} 2.5$ indicates high involvement, $\bar{x}_{<} 2.5 \geq 2.0$ indicates moderate involvement, $\bar{x}_{<} 2.0$ indicates low involvement. Perceived factors influencing the involvement of youths in poultry production was measured on a four points Likerttype rating scale of strongly agree (4), agree (3), disagree (2), strongly disagree (1). The benchmark mean of 2.50 was used for decision making. Thus: any mean response that is less than 2.50 was not regarded as a factor, while any mean score that is equal or greater than 2.50 was regarded as a factor.

The hypothesis on the influence of the socio-economic characteristics of the youths on their involvement in poultry production was tested using ordinary least square regression analysis.

This was tried on the four functional forms of linear, exponential, double-log and semi-log in other to make choice for the lead model.

The functions were explicitly specified thus:

Linear function:

$Y=b_{0}+b_{1} X_{1}+b_{2} X_{2}+b_{3} X_{3}+b_{4} X_{4}+b_{5} X_{5}+b_{6} X_{6}+b_{7} X_{7}+b_{8} X_{8}+e_{-}$ $-1$

Semi log function:

$Y=\ln b_{0}+b_{1} \ln X_{1}+b_{2} \ln X_{2}+b_{3} \ln X_{3}+b_{4} \ln X_{4}+b_{5} \ln X_{5}+b_{6} \ln X_{6}+b_{7} \ln X_{7}+b_{8} \ln X_{8}+e_{i}--$ 2

Double log function:

$\log Y=\ln b_{0}+b_{1} \ln X_{1}+b_{2} \ln X_{2}+b_{3} \ln X_{3}+b_{4} \ln X_{4}+b_{5} \ln X_{5}+b_{6} \ln X_{6}+b_{7} \ln X_{7}+b_{8} \ln X_{8}+$ $e_{i} \ldots . . .3$

Exponential function: $\log Y=b_{0}+b_{1} X_{1}+b_{2} X_{2}+b_{3} X_{3}+b_{4} X_{4}+b_{5} X_{5}+b_{6} X_{6}+b_{7} X_{7}+b_{8} X_{8}$ $+\mathrm{e}_{\mathrm{i}} . .4$ 
Where:

$\mathrm{Y}=$ dependent variable (mean score of youths' involvement in agripreneurship)

$e_{i}=$ stochastic error Term

$b_{0}=$ Intercept

$b_{1}-b_{8}=$ parameters to be estimated

$\mathrm{X}_{1}-\mathrm{X}_{10}=$ independent variables (Socio-economic variables)

Where:

$\mathrm{X}_{1}=$ Age (years)

$X_{2}=$ Gender $(1=$ male, $0=$ female $)$.

$X_{3}=$ Educational level (no. of years spent in school)

$\mathrm{X}_{4}=$ Extension contact (No of times of visit)

$X_{5}=$ Availability of credit $(Y e s=1$, No $=0)$

$\mathrm{X}_{6}=$ Marital Status $(1=$ married, $0=$ single $)$

$\mathrm{X}_{7}=$ Availability of land $(\mathrm{Yes}=1, \mathrm{No}=0)$

$\mathrm{X}_{8}=$ Co-operative membership $(\mathrm{Yes}=1, \mathrm{No}=0)$

$\mathrm{X}_{9}=$ Farming Experience (years)

$X_{10}=$ Income (Naira)

ei $=$ error term

\section{Results and Discussion}

\section{Extent of Youth's Involvement in Poultry Production}

Table 1 shows the result of the extent of youths' involvement in poultry production in the study area. The result reveals the foremost poultry production activities engaged in by the youths included feeding $\left(\bar{x}_{=}=2.81\right)$, packing and replacement of litters $\left(\bar{x}_{=}\right.$ 2.59) and vaccination/medication $(\bar{x}=2.54)$. These are being ranked $1^{\text {st }}, 2^{\text {nd }}$, and $3^{\text {rd }}$ respectively. Brooding $(\bar{x}=1.95)$ and hatchery $\left(\bar{x}_{=}=1.84\right)$ were the least participated poultry production activities by the youths in the study area. However, the grand mean of 2.37 indicates that there was moderate level of participation of youths in poultry production. The involvement in various poultry production activities implies some level of interest among the youths as their source of livelihood. The result is in agreement with the findings of Adeniran et al (2018), Ekerete, Ekanem, and Umoh (2017) which indicated active participation of the youths in poultry production. 
Creative Commons User License: CC BY-NC-ND

Abstracted by: EBSCOhost, Electronic Journals Service (EJS),

Google Scholar, Journal Seek, Scientific Commons,

Food and Agricultural Organization (FAO), CABI and Scopus
Journal of Agricultural Extension

Vol. 24 (4) October, 2020

ISSN(e): 24086851; ISSN(Print); 1119944X

http://journal.aesonnigeria.org

http://www.ajol.info/index.php/iae

Email: editorinchief@aesonnigeria.org

Table 1: Extent of rural youth's involvement in poultry production

\begin{tabular}{lcc}
\hline Poultry production activities & $\bar{x}$ & Standard deviation \\
\hline Feeding & $2.81^{\star \star *}$ & 0.455 \\
Marketing of poultry & $2.72^{\star \star *}$ & 0.488 \\
Packing and replacement of litters & $2.59^{\star \star *}$ & 0.558 \\
Vaccination/Medication & $2.54^{\star \star *}$ & 0.578 \\
Keeping of records & $2.44^{\star *}$ & 0.754 \\
Packing and sorting of eggs & $2.43^{\star *}$ & 0.496 \\
Feed production & $2.25^{\star *}$ & 0.638 \\
Transportation of poultry products & $2.11^{\star *}$ & 0.765 \\
Brooding & $1.95^{\star}$ & 0.408 \\
Hatchery & $1.84^{\star}$ & 0.745 \\
Grand mean & $2.37^{\star *}$ & \\
\hline
\end{tabular}

${ }^{* * *}=$ high, ${ }^{* *}=$ moderate, ${ }^{*}=$ low. Source: Field survey, 2019

\section{Perceived Factors that Influence the Involvement of the Youths in Poultry Production}

Table 2 shows the result of the factors that influence the involvement of youths in poultry production in the study area. The results reveal that the foremost factors influencing the youths' involvement in poultry production in the study area were income $(\bar{x}=3.69)$, cost of feed $(\bar{x}=3.45)$, availability of land $(\bar{x}=3.33)$ and cost of stocking bird $(\bar{x}=3.23)$. These were ranked $1^{\text {st }}, 2^{\text {nd }}, 3^{\text {rd }}$, and $4^{\text {th }}$ respectively. Income is a very important factor in the commencement and operation of any business venture. Income is a major deterrent factor to youths' involvement in poultry production as poultry production demands a lump sum of income for its operational expenses. Other factors such as cost of feed and cost of stocking bird are hinged to the income factor. Moreover, the patriarchal land tenure system practiced within the Eastern region where land is apportioned to the male children mostly at the demise of their father constitutes a major hindrance to youths' involvement in poultry production and other agricultural ventures. Interest of the youths in poultry business $(\bar{x}=3.04)$ was also identified as another factor influencing the youths' participation in poultry production.

Table 2: Factors influencing youths' involvement in poultry production

\begin{tabular}{lcc}
\hline Factors & $\bar{x}$ & Standard deviation \\
\hline Income & 3.69 & 0.482 \\
Cost of feed & 3.45 & 0.684 \\
Availability of land & 3.33 & 0.524 \\
Cost of stocking bird & 3.23 & 0.590 \\
Interest in poultry business & 3.04 & 0.492 \\
Poultry production skill & 2.47 & 0.542 \\
Cost of medication & 2.05 & 0.604 \\
Labour cost & 1.67 & 0.833 \\
Grand mean & $\mathbf{2 . 8 6}$ & \\
\hline
\end{tabular}

Source: Field survey, 2019 
Creative Commons User License: CC BY-NC-ND

Abstracted by: EBSCOhost, Electronic Journals Service (EJS),

Google Scholar, Journal Seek, Scientific Commons,

Food and Agricultural Organization (FAO), CABI and Scopus
Journal of Agricultural Extension

Vol. 24 (4) October, 2020

ISSN(e): 24086851; ISSN(Print); 1119944X

http://journal.aesonnigeria.org

http://www.ajol.info/index.php/iae

Email: editorinchief@aesonnigeria.org

\section{Influence of Socio-Economic Characteristics on Youths Involvement in Poultry Production}

Table 3 shows the result of the ordinary least square regression analysis of the influence of socio-economic characteristics of the youths on their involvement in poultry production in the study area.

The exponential function was chosen as the lead based on the intensity of F-ratio and co-efficient of determination, as well as the number of significant variables and their conformity with the apriori expectations. From Table, the F-ratio of 4.267 which is significant at $1 \%$ significant level indicates the goodness-of-fit of the model. The co-efficient of determination $\left(R^{2}\right)$ of 0.642 indicates that about $64.2 \%$ of the variations in youth involvement in poultry production were explained by their socioeconomic variables.

From Table 3, the co-efficient of age was positive and significant at $5 \%$ significant level. This implies that the involvement of the youths in poultry production increases as their age increases. This could be due to the fact that increase in age among youths could entail increase in maturity and responsibility. Hence, the aged youths might have more responsibilities which could make them engage more in production activities so as to meet the arrays of needs and demand lying on their neck. This is contrary to the findings of Ezeano et al (2017) which shows that participation of youths in poultry production decreases with increase in age.

The co-efficient of membership to co-operative was positive and significant at $5 \%$ significant level. This implies that the tendency of involvement in poultry production activities increases with membership to co-operative societies. Hence, youths who belong to co-operative societies are likely to involve more in poultry production activities. This could due to the training and enlightenment given by co-operative societies to their members which make them more open to engage in production activities.

The co-efficient of income was also positive and significant at $1 \%$ significant level. This implies that involvement of youths in poultry production activities increases with increased income. This could be due to the fact that the higher the income a farmer earns, the more he/she will be more proactive in involving and undertaking the production activities he/she is engaged in.

The co-efficient of years of experience was also positive and significant at $5 \%$ probability level. This implies that as the years of experience of the youths increases, their tendency of involving in poultry production activities also increases. This is in agreement with Adeniran et al (2018) and Ezeano et al (2017) who posited that years of experience play significant roles in rural youth involvement in poultry production. According to Adeniran et al (2018), poultry production requires some level of expertise in terms of knowledge which is accumulated over a considerable 
Creative Commons User License: CC BY-NC-ND

Abstracted by: EBSCOhost, Electronic Journals Service (EJS), Google Scholar, Journal Seek, Scientific Commons,

Food and Agricultural Organization (FAO), CABI and Scopus
Journal of Agricultural Extension

Vol. 24 (4) October, 2020

ISSN(e): 24086851; ISSN(Print); 1119944X

http://journal.aesonnigeria.org

http://www.ajol.info/index.php/iae

Email: editorinchief@aesonnigeria.org

Table 3: Influence of socio-economic characteristics on youth's involvement in poultry production

\begin{tabular}{|c|c|c|c|c|}
\hline Parameters & Linear & +Exponential & Semi-log & Cob Douglas \\
\hline Constant & $\begin{array}{c}20.959 \\
(15.806)^{* * *}\end{array}$ & $3.061(56.551)^{* * *}$ & $1.200(6.496)^{* * *}$ & $2.248(4.581)^{* * *}$ \\
\hline Age & $0.084(2.347)^{* *}$ & $0.013(2.506)^{\star *}$ & $3.634(1.224)$ & $-0.142(-1.216)$ \\
\hline Sex & $-0.121(-0.304)$ & $-0.003(-1.202)$ & $-1.374(-1.810)^{*}$ & $-0.054(-1.792)^{*}$ \\
\hline Education & $0.021(0.582)$ & $0.001(0.536)$ & $13.606(4.467)^{*+*}$ & $0.539(4.499)^{\star * * *}$ \\
\hline Marital Status & $0.020(1.340)$ & $0.003(1.134)$ & $-0.621(-0.577)$ & $-0.027(-0.642)$ \\
\hline Household size & $-0.035(-0.270)$ & $-0.002(-1.442)$ & $2.770(2.410)^{\star \star}$ & $0.110(2.434)^{\star \star}$ \\
\hline $\begin{array}{l}\text { Membership to Co- } \\
\text { operative }\end{array}$ & $1.126(2.676)^{\star \star \star x}$ & $0.042 \quad(2.446)^{* *}$ & $(0.293)$ & $(0.439)$ \\
\hline Income & $\begin{array}{l}2.706 \mathrm{E}-6 \\
(2.803)^{\star * \star}\end{array}$ & $1.111 \mathrm{E}-7(2.820)^{\star \star \star}$ & $-0.348 \quad(-0.628)$ & $-0.013 \quad(-0.580)$ \\
\hline Access to land & $0.143(1.299)$ & $0.006(1.283)$ & $1.297(1.031)$ & $0.055(1.121)$ \\
\hline Years of experience & $0.007(0.134)$ & $0.016(2.186)^{* *}$ & $0.533(0.761)$ & $0.018(0.669)$ \\
\hline Access to credit & $0.858(1.585)$ & $0.035(1.781)^{*}$ & $1.256(1.266)$ & $0.052(1.329)$ \\
\hline Extension contact & $0.369(2.178)^{* *}$ & $0.015(2.132)^{* *}$ & $0.530(0.428)$ & $0.017(0.352)$ \\
\hline R-square & 0.747 & 0.763 & 0.686 & 0.712 \\
\hline R-Adjusted & 0.626 & 0.642 & 0.561 & 0.596 \\
\hline $\mathrm{F}$ - ratio & $4.341^{* * *}$ & $4.267^{* \star *}$ & $3.846^{* * *}$ & $3.918^{* * *}$ \\
\hline
\end{tabular}

Source: Computed from field survey, 2019

** $P \leq 0.05,{ }^{* * *} P \leq 0.01$

$+=$ Lead Equation and the values in bracket are the t-values.

period. Ezeano et al (2017) also posited that experience youth farmers are competent, set realistic goals and are committed to farm management activities.

Similarly, the co-efficient of extension contact was positive and significant at $5 \%$ significant level. This implies that the higher the extension contact of the youths, the higher their participation in poultry production activities. Extension contact create an avenue for the farmers to receive vital information on improved agricultural technologies, hence makes the farmer more open to involve more in potent agricultural production activities necessary in ensuring increased productivity.

Since the F-ratio is significant, the null hypothesis which states that the socioeconomic characteristics of the youths have no significant influence on their involvement in poultry production in Abia State is hereby rejected. Hence, the alternate hypothesis is accepted that the socio-economic characteristics of the youths have significant influence on their involvement in poultry production. 
Creative Commons User License: CC BY-NC-ND

Abstracted by: EBSCOhost, Electronic Journals Service (EJS),

Google Scholar, Journal Seek, Scientific Commons,

Food and Agricultural Organization (FAO), CABI and Scopus
Journal of Agricultural Extension

Vol. 24 (4) October, 2020

ISSN(e): 24086851; ISSN(Print); 1119944X

http://journal.aesonnigeria.org

http://www.ajol.info/index.php/iae

Email: editorinchief@aesonnigeria.org

\section{Conclusion and Recommendation}

Age, membership to co-operative, years of experience, income and extension contact were significant socioeconomic variables influencing the involvement of the youths in poultry agripreneurship. The cost of feed should be subsidized to ensure that it is fairly affordable to young poultry farmers and other individuals that may venture into poultry production. The government should evolve policies which will ensure that land can be made available to genuine youths who want venture into agriculture in order to help them overcome land acquisition constraint. Furthermore, the government and development agencies should develop potent micro credit scheme to ensure that youths who might want to venture into agripreneurship have access to loan/credit. This can be achieved through the establishment or enhancement of micro credit scheme and microfinance banks targeted at youths at low interest rate.

\section{References}

Adedeji, O.S., Amao, S.R., Alabi, T.J, Opebiyi, O.B. (2015). Assessment of poultry production system in Ilesha West Local Government Area of Osun State, Nigeria. Scholars Journal of Agriculture and Veterinary Sciences; 1(1): 20-27.

Adeniran, A. A., Akinnagbe, O. M, Obute, J. E. and Olatunji, T. D. (2018). Rural youth involvement in poultry production in Ido Local Government Area of Oyo State, Nigeria. Asian Research Journal of Agriculture, 9(2): 1-7.

Ajani, E. N., Mgbenka, R. N., Onah, O. (2015). Empowerment of youths in rural areas through agricultural development programmes: Implications for poverty reduction in Nigeria.

International Journal of Research in Agriculture and Forestry, 2(2): 34-41.

Akpan, S. B., Patrick, I.V., James, S.U and Agom, D. I. (2015). Determinants of decision and participation of rural youth in agricultural production: A case study of youth in Southern region of Nigeria. Russian Journal of Agricultural and Socio-Economic Sciences, 7(43): 35-48.

Ekerete B.I, Ekanem J.T, and Umoh I.U. (2017). Determinants of youth's participation in poultry farming in the integrated farmers scheme (IFS) of Akwa lbom State, Nigeria. Journal of Community and Communication Research, 2(1):6-12.

Ezeano, C.I, Ume, S.I, Okeke, C. C, Gbughemobi, B O (2017). Socio-economic determinant factors to youths participation in broilers production in Imo State of Nigeria. International Journal of Research and Review, 14(1): 136 - 143.

Food and Agriculture Organization FAO, (2017). Youth and agriculture: key challenges and concrete publication in collaboration with Technical Center for Agriculture and Rural Cooperation and the International Fund for Agricultural Development. Scientific Papers Series Management, Economic Engineering in Agriculture and Rural Development, 17(3): 427-434. 
Creative Commons User License: CC BY-NC-ND

Abstracted by: EBSCOhost, Electronic Journals Service (EJS), Google Scholar, Journal Seek, Scientific Commons,

Food and Agricultural Organization (FAO), CABI and Scopus

http://eoi.citefactor.org/10.11226/v24i4
Journal of Agricultural Extension

Vol. 24 (4) October, 2020

ISSN(e): 24086851; ISSN(Print); 1119944X

http://journal.aesonnigeria.org

http://www.ajol.info/index.php/iae

Email: editorinchief@aesonnigeria.org

Inyang, E. B., and Eko, P. M. (2015). Correlates analysis of poultry entrepreneurial capacity development among young adults in Akwa Ibom State, Nigeria. International Journal of Academic Research and Reflection, 3(6): 57-66.

Haruna, Samuel, and Ibinayo, (2020). Economic and scale efficiency of broiler production in the Federal Capital Territory, Abuja Nigeria: A data envelopment analysis approach. Russian Journal of Agricultural and Socio-Economic Sciences, 7(103): 131 - 139.

Heinke, H., Alexandra, C., and Ludwig, T. (2015). The Poultry Market in Nigeria: Market Structures and Potential for Investment in the Market. International Food and Agribusiness Management Association (IFAMA), 18(10): 197 - 222.

National Bureau of Statistics (2012). Labour force statistics. Federal Republic of Nigeria. www.nigerianstat.gov.ng.

National Bureau of Statistics (2017). Demographic Statistics Bulletin.

Nwarieji, F.E., Obi, B.C. and Ejiofor, T. (2017). The study of entrepreneurial skills required by small scale poultry farmers in Orumba North and South Local Government Area of Anambra State, Nigeria. African Journal of Agricultural Research, 2(33): 2586-2597.

Nwigbo, S. U., Mbam, B. N., Biam, C. (2016). Determinants of agripreneurship among the rural households of Ishielu Local Government Area of Ebonyi State. Journal of Biology, Agriculture and Healthcare, 6(13): 3-10.

Onuekwusi, G. C, Nmeregini, D. C., and Amanze, R. (2019). Attitude of rural youths towards agripreneurship in Isiala Ngwa South Local Government Area, Abia State, Nigeria. Proceedings of the $24^{\text {th }}$ Annual Conference of the Agricultural Extension Society of Nigeria, 7th -10th April, 2019, Raw Material Research and Development Council, Abuja Nigeria.

Osuji, M. N. (2019). Assessment of factors affecting poultry (broiler) production in Imo State, Nigeria. Asian Journal of Agricultural Extension, Economics \& Sociology, 35(2): 1-6.

Umar, M. L., Envuladu, E.A., Mohammad, A.M. and Wali, N. Y. and Mahmoud, H. M. (2015): Perceptions and attitude towards entrepreneurship education programme, and employment ambitions of final year undergraduate students in Kano, Northern Nigeria. International Journal of Education and Research, 3(11): 45-53. 